\title{
Time equals money? Valuing ecosystem-based adaptation in a developing country context
}

\author{
Liselotte C. Hagedoorn, ${ }^{\star}$ (D) Mark J. Koetse, Pieter J. H. van Beukering, and \\ Luke M. Brander \\ Institute for Environmental Studies (IVM), VU University Amsterdam, Amsterdam, The Netherlands \\ ${ }^{*}$ Corresponding author. E-mail: liselotte.hagedoorn@vu.nl
}

(Submitted 30 August 2019; revised 18 December 2019; accepted 05 February 2020; first published online 30 March 2020)

\begin{abstract}
To guide investments in ecosystem-based adaptation (EbA) in developing countries, numerous stated preference valuation studies have been implemented to assess the value of ecosystem services. These studies increasingly use time payments as an alternative to money. There is limited knowledge, however, about how to convert time to money and how the type of payment affects willingness to pay (WTP). In this study, the results of choice experiments using time and money payments are compared in the context of EbA measures in Vietnam. Six, of which five individual-specific, conversion rates are applied. WTP estimates are found to be higher for time payments. Moreover, the type of payment vehicle as well as the conversion rate has substantial effect on mean WTP and WTP distributions. We discuss implications of these results for the conversion of time to money and the use of resulting WTP estimates in cost benefit analyses in developing countries.
\end{abstract}

Keywords: discrete choice experiments; ecosystem-based adaptation; environmental valuation; monetary payment vehicle; time payment vehicle; willingness-to-pay

JEL classification: C1; Q5; Q51; Q57

\section{Introduction}

Developing countries are highly vulnerable to current and future climate change (Parker, 2006; Jongman et al., 2015). Apart from mitigating climate change, there is a need to increase adaptation efforts. Besides structural measures, such as seawalls or dikes, adaptation efforts can include ecosystem-based adaptation (EbA) measures. EbA uses biodiversity and ecosystem services (ES) as part of an adaptation strategy, and includes the sustainable management and restoration of ecosytems to help people adapt to the adverse effects of climate change (Secretariat of the Convention on Biological Diversity, 2009). Moreover, EbA could play a role in the achievement of several Sustainable Development Goals and in compliance to the Sendai Framework for Disaster Reduction, policies that are at the heart of current climate adaptation discussions. Next to 
its adaptation potential, EbA can prevent or revert ongoing environmental degradation that is threatening human health and life-support systems (Gupta et al., 2019; UN Environment, 2019). However, in spite of its potential benefits, current investment in EbA is limited; for instance, less than 1 per cent of total investments in water resources management is spent on ecosystem-based solutions (WWAP/UN-Water, 2018).

To guide investments and to make well-informed decisions on the implementation and design of EbA, there is a need for accurate estimation of the welfare effects of these measures. Stated preference valuation studies can fill this gap by providing information to decision makers on the economic value of the ES that are affected by the EbA measures. The results of these studies, however, are subject to criticism concerning challenges that are specific to developing countries, such as language barriers, differences in cultural context, and comparatively limited use of money as a form of income or medium of exchange (Whittington, 2002; Alam, 2006; Christie et al., 2012; Gibson et al., 2016).

In stated preference valuation studies, it is common practice to incorporate a monetary payment, such as a monthly contribution to a fund or increases in tax payments. This payment vehicle is required for the calculation of willingness to pay (WTP). In a developing country context, however, a lack of market integration and dependence on subsistence livelihoods implies that many households may have low monetary incomes, and hence using a monetary payment vehicle can lead to a number of interrelated problems regarding WTP (Alam, 2006; Kenter et al., 2011; Gibson et al., 2016). First, the resulting WTP values might be an underestimation because respondents do not have the financial resources required to express their preferences for the ES. Second, limited incomes and lack of familiarity with money payments for goods and services in general, and ES in particular, may result in methodological issues such as non-attendance or protesting behaviour (Gibson et al., 2016). Third, due to the previous two problems, the results of a valuation study using a monetary payment vehicle might fail to accurately represent certain groups in society, such as subsistence or poorer households, due to their (missing) relation with money (Alam, 2006; Gibson et al., 2016).

This problem stems from households in developing countries facing relatively tight monetary constraints, although they are not necessarily poor in terms of time and natural resources. Moreover, WTP is a function of a person's wealth rather than monetary income and, especially in developing countries, non-monetary goods may be a significant component of someone's wealth. Alternative payment vehicles that have therefore been trialed in developing country contexts include bags of rice (Shyamsundar and Kramer, 1996) and meals (Diafas et al., 2017). The most popular alternative to a monetary payment vehicle, however, is payment in terms of time (e.g., Hardner, 1996; Kamuanga et al., 2001; Hung et al., 2007; O’Garra, 2009; Abramson et al., 2011; CasiwanLaunio et al., 2011; Rai and Scarborough, 2013; Vondolia et al., 2014; Gibson et al., 2016; Pondorfer and Rehdanz, 2018; Vondolia and Navrud, 2019). In general, the studies that use time payment vehicles find that this payment vehicle is highly accepted by respondents, and is often preferred over money payments (Kamuanga et al., 2001; Alam, 2006; Hung et al., 2007; O'Garra, 2009; Abramson et al., 2011; Casiwan-Launio et al., 2011; Rai and Scarborough, 2013; Vondolia et al., 2014).

However, there are also several problematic issues with using time as a payment vehicle. One that especially stands out is the conversion of time to money values. This step is required for the estimation of monetary WTP estimates that can be used in cost benefit analyses. So far, stated preference studies in developing countries that convert time into money have mostly applied a generic market wage rate as the conversion rate (Alam, 2006; O'Garra, 2009; Vondolia et al., 2014; Gibson et al., 2016). This approach is often criticized due to heterogeneity in wages and values of time (Czajkowski et al., 2019; 
Lloyd-Smith et al., 2019) as well as because respondents might intend to invest leisure time rather than working time. Rai and Scarborough (2013) and Abramson et al. (2011) both estimate values of time that are lower than the market wage rate by calculating the opportunity cost of labor from discrete choice experiments that included both types of payment. Consequently, some studies used a so-called leisure rate based on the study by Cesario (1976), which finds that the value of leisure time is between $25-50$ per cent of the wage rate, and is being applied in the literature as $1 / 3$ of the wage rate (O'Garra, 2009; Casiwan-Launio et al., 2011). However, there are more recent studies that show that the value of leisure time can be much higher than $1 / 3$ of the wage rate and differs per, for instance, income group and employment situation (Feather and Shaw, 1999; Alvarez-Farizo et al., 2001; Larson and Shaikh, 2004; Larson et al., 2004; Lee and Kim, 2005; Jara-Díaz et al., 2008).

Only a few of those studies that convert the obtained time values into money thereafter compare the WTP estimates that result from both time and money payment vehicles (Alam, 2006; O'Garra, 2009; Casiwan-Launio et al., 2011; Vondolia et al., 2014; Gibson et al., 2016). These studies have drawn varying conclusions regarding the differences in WTP estimates resulting from time and money payment vehicles. Of the studies that used a generic market wage rate to convert time into money, two find higher WTP estimates for the time payment vehicle (Alam, 2006; O'Garra, 2009), one finds comparable WTP estimates (Gibson et al., 2016) and one finds lower estimates for the time payment vehicle (Vondolia et al., 2014). One study applied an individual-specific daily income and found comparable WTP distributions for both payment vehicles (Tilahun $e t$ al., 2015). Then, for the comparisons that were made using a generic leisure rate based on Cesario (1976), Casiwan-Launio et al. (2011) found higher WTP estimates for the time payment vehicle while O'Garra (2009) found comparable WTP estimates. In conclusion, the literature is inconclusive about the differences in WTP across time and money payment vehicles and the conclusion can also differ depending on the time-to-money conversion rate that is applied.

This study is the first to conduct a stated preference valuation study in the context of the implementation of EbA measures in a developing country context and compare the WTP estimates of time and money payment vehicles using six conversion rates. These conversion rates include the commonly applied generic market wage rate and five individual-specific time-to-money conversion rates. These five conversion rates include individual-specific wage rates, two different leisure rates and two weighted values of time. The results add to the limited literature about how WTP estimates differ across time and money payment vehicles and on the use of time-to-money conversion rates, information that is crucial for the estimation of accurate welfare effects of EbA measures. The results can be used by stated preference practitioners to improve the quality of information provided to decision-makers and to guide investments in EbA.

The remainder of the paper is structured as follows. Section 2 outlines the study sites included in this research and the methods that are applied. Section 3 describes the results, and section 4 provides a discussion of the results and draws conclusions.

\section{Study sites and methods}

\subsection{Study sites}

Vietnam is an Asian developing country that is currently experiencing rapid exploitation of natural resources, climate change impacts and population growth. Vietnam is furthermore considered as one of the most vulnerable countries with respect to climate-related 

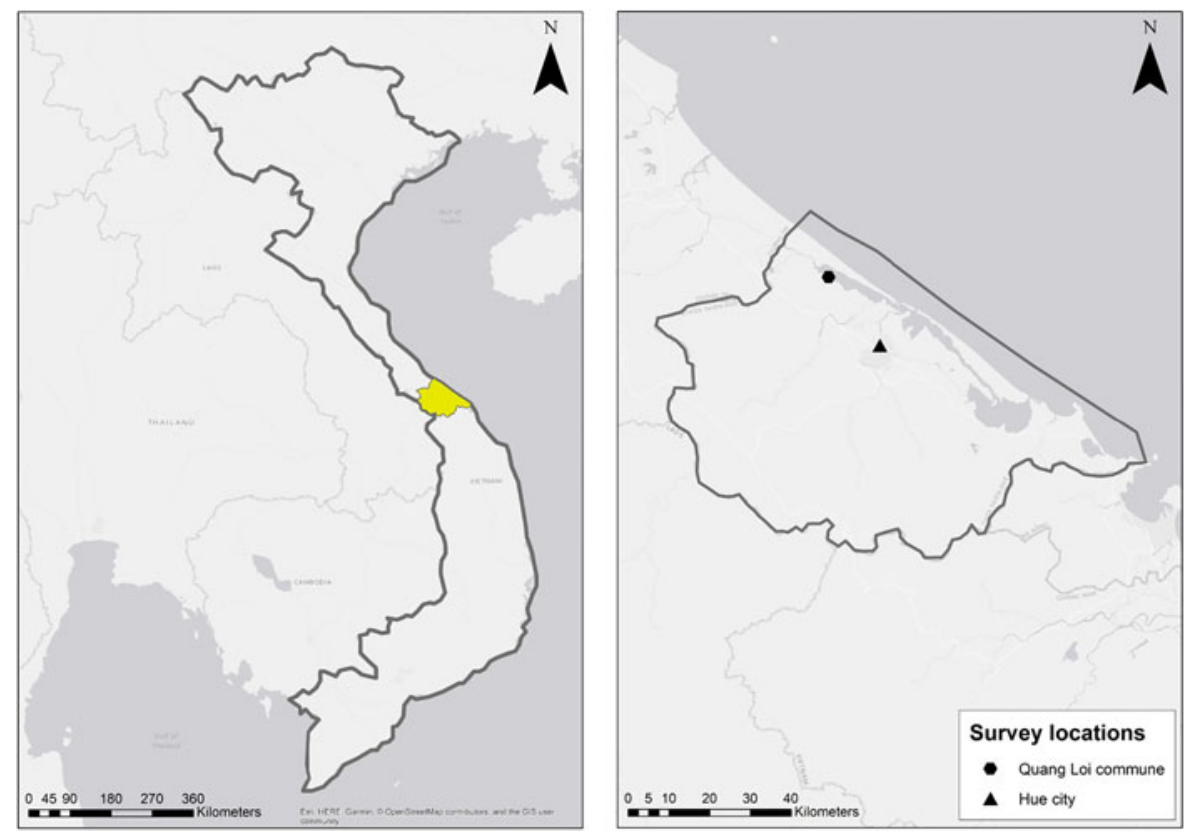

Figure 1. Location of Thùa Thiên-Huế province and the case study sites Huế City $\left(16^{\circ} 28^{\prime} 41.8^{\prime \prime} \mathrm{N} 107^{\circ} 34^{\prime} 49.2^{\prime \prime} \mathrm{E}\right)$ and Quảng Lợi commune (16 $\left.37^{\prime} 24.8^{\prime \prime} \mathrm{N} 107^{\circ} 27^{\prime} 24.1^{\prime \prime} \mathrm{E}\right)$.

Source: Hudson et al. (2019), based on Esn, HERE, Carmin, OpenStreetMap contributers and the GIS user community.

hazards (e.g., Dasgupta et al., 2009). This study focusses on the province of Thùa Thiên-Huế, a coastal province in Central Vietnam, where frequent flood events - a total of 40 between 1975 and 2005 (Bubeck et al., 2012) - have resulted in high damage costs and loss of life, and are expected to increase in frequency. In November 2007, typhoon Damrey caused a flood that resulted in the loss of nine lives and US\$36 million in damages (KTTV, 2017; Vietnam News, 2017).

Therefore, with the broader purpose of examining the benefits of investing in EbA measures, two study sites within Thùa Thiên-Huế province (see figure 1) were selected for implementation of community-led EbA measures as part of the Global Resilience Partnership Water Window. The first is an urban study site, the old town of Huế City, and the second is a coastal study site, Quảng Lợi commune in the coastal district of Quảng Điền. In both sites, the community was involved in the design of the adaptation measures and community events were organized to communicate the benefits and management aspects of the implemented measures. ${ }^{1}$

Adjacent to Quảng Lợi commune, in the Tam Giang lagoon, a mangrove forest is being restored by replanting mangroves so as to create a buffer against storm and flood events. Simultaneously, the mangroves are also expected to increase the abundance of seafood, improve the overall water quality, provide erosion control, attract tourists,

\footnotetext{
${ }^{1}$ See DKKV (2019) for more information on the project and implementation.
} 
and positively influence rice and aquaculture production. Many of Thùa Thiên-Huế's coastal communities suffer from poverty resulting from unstable livelihoods and insufficient resources to recover from disasters. Mangrove restoration can potentially provide additional means to improve income security.

In the old town of Huế City, a network of existing urban ponds are being restored to increase drainage capacity, similarly aimed at reducing flood and storm damages. Currently the connections between the ponds are blocked, which means the water flow is limited or stopped completely. Ancillary benefits are a cooling effect, improved aesthetics, suitability for recreation activities, tourist attraction, and increases in aquaculture and lotus production. Huế City is located on the Perfume River and has around 350,000 inhabitants. The city is a popular tourist destination due to its historic monuments, such as the Imperial City, and earned the status of UNESCO World Heritage Site in 1993.

\subsection{Methods}

\subsubsection{Survey approach}

In order to estimate the benefits of EbA, a discrete choice experiment (DCE), embedded in a household survey, was applied. To develop the DCE and household survey, an exploratory pre-test survey was implemented first, followed by a pilot test, after which the main study was conducted. In preparation for the field work, a team of 14 local enumerators, consisting of staff from Centre for Social Research and Development (CSRD) and students from Huế University, received a four-day training.

Data collection took place between June and September 2017. For each test, 80 respondents were surveyed. For the main study, 505 respondents were interviewed in the coastal as well as the urban study site. In each site, the sampling frame consisted of an estimate of the number of households. Although an official list of households was not available, community leaders were able to provide a reliable estimate for the sampling procedure. The target was to interview household heads or their partners. Respondents were asked to respond on their own behalf, although some questions focused on the entire household, including questions related to food consumption, income and income sources, and resource extraction. In both study sites, areas were selected that evidently benefited from the restoration activites. In Huế City this includes households living in the old town near the ponds. In Quảng Lợi commune this includes households from eight villages living on the lagoon side of the road adjacent to the mangroves. In the latter, households were sampled according to each village's relative size in terms of households. Respondents were interviewed in their homes and, to ensure a representative sample, the households were randomly selected. If a household had already participated in the pilot survey, they were excluded from the DCE sample. The respondents were evenly divided between the experiment with a time payment vehicle and the experiment with a money payment vehicle. This was done by presenting the first respondent with a time experiment, the second with a money experiment, the third with a time experiment, and so on. Kobo Toolbox software was used to record the answers of each interview. ${ }^{2}$ More details on the sampling approach can be found in Hudson et al. (2019), who note that the sample is representative of the province as a whole.

\footnotetext{
${ }^{2}$ See https://www.kobotoolbox.org/ for access to this software.
} 


\subsubsection{Discrete choice experiment}

The DCE is a stated preference valuation method that is used to elicit values of respondents for specified changes in a good or service. It involves asking survey respondents to make repeated choices between multi-attribute descriptions of a good or service. By observing the trade-offs that are made between attributes, it is possible to estimate their relative values. The main theoretical underpinnings of the DCE method are derived from the characteristics theory of value (Lancaster, 1966) and random utility theory (McFadden, 1974; Hanley et al., 1998). The choice experiment method attempts to measure the preferences that people have for characteristics of the goods and services they consume, which in this study are the quality and quantity of ES. ${ }^{3}$

Pre-test survey. The pre-test survey was aimed at measuring the suitability of various payment vehicles as well as at making a selection of the most important ES that are affected by the EbA measures. To select the payment vehicles, respondents were asked to score a list of payment vehicles based on coverage, trust, acceptability and practicality (Morrison et al., 2000). In both coastal and urban study sites, the two payment vehicles that scored highest and are therefore perceived as most credible and consequential were a monthly monetary contribution to a community fund for the EbA measures and time spent on the EbA measures. The information on the most important ES was used to select the other attributes for the DCE. For the coastal area, the selected ES included protection from storms and floods, abundance of seafood in the lagoon, and tourism to the mangroves. In the urban area, protection from storms and floods, suitability for recreation, and tourism in Huế City were selected as the most relevant ES. Other questions in the survey concerned the measurement of current levels of the ES enjoyed by the respondents as well as the respondents' maximum WTP via each payment vehicle, so as to obtain an initial range of maximum WTP. The answers to these questions provided input for the selection of attribute levels in the DCE.

Pilot test. To ensure consequentiality, plausible levels for the payment vehicles and ES as well as sufficient information on the handling of payments and delivery of the ES are essential (Carson and Groves, 2007; Johnston et al., 2017). Therefore, the pilot test was implemented aimed at examining the credibility of the presented situations, clarity of the choice questions, descriptions of the attributes, and pictures used to describe the attribute levels. Moreover, the pilot test was used to estimate an initial value of time in order to relate the attribute levels of both payment vehicles in the DCE for the purpose of comparability. The pilot test choice cards included both payment vehicles as well as the three ES attributes, each of which contained four attribute levels. By including both payment vehicles in one experiment, we aimed to obtain the opportunity cost of time following Rai and Scarborough (2013). Each choice card included three options: Management A, Management B and an opt-out called 'No Management', for which all the attributes are at their least favorable level (i.e., low) and the payment vehicles at their most favorable level (i.e., 0). The opt-out described the current situation in the communities as based on the pre-test survey results, and was found to be credible by the respondents. The pilot also tested the remaining questions in the survey. To further ensure plausible payment levels and to estimate an initial value of time, additional questions were included asking for the respondents' maximum WTP for the restoration activities via the community fund and via the time spent on restoration activities.

\footnotetext{
${ }^{3}$ See Johnston et al. (2017) for an introduction, history and set of guidelines on stated preference studies on environmental goods.
} 
Main DCE. The attribute types and attribute levels for both the coastal and urban choice experiment can be found in tables 1 and 2. Two different experiments were designed for each area, one for each payment vehicle. Due to choice formulation issues during the pilot test, which resulted in insufficient quality priors, we used an orthogonal instead of a $D$-efficient statistical design for the DCE, in which dominant choices were identified and adjusted. To have similar levels of payment for the time and the monetary experiments, we relate the attribute levels using a value of time obtained from the pilot survey. For this we use the pilot survey questions on maximum WTP for the restoration activities via both time and money. This value of time is calculated by dividing each respondents' WTP for the restoration activities via the community fund by the willingness to spend time on the restoration activities, and by taking the median of the resulting variable (see equation (1)). For the urban study site, this resulted in a value of time of 5,000 Vietnamese dong (VND) per hour; for the coastal study site, this was a little over VND3,000 per hour. ${ }^{4}$ The results to these pilot survey questions were also used to decide on the payment levels in all experiments.

$$
\text { Value of time }=\text { median }\left(\frac{\text { Maximum WTP per respondent via community fund }}{\text { Maximum WTP per respondent via time in hours }}\right)
$$

As shown in tables 1 and 2, the attributes have four levels and the payment vehicles have five. The same design was used for both the time and money payment vehicles in both coastal and urban experiments. For each experiment, 60 choice cards were generated that were divided over six versions. Three management options are presented on each choice card. The attribute levels that are included in the opt-out (No Management) were only used to describe this option and did not occur in either Management A or B.

The payment vehicles were presented to the respondents as coercive, meaning that everyone in the community would be asked to contribute time or money to the project. The payment vehicles were similar in terms of description so that the work that would be undertaken is the same whether paid for with collected money or volunteered time. This includes guarding and cleaning the restored ecosystems, building fences or look-outs, enforcing regulations and planting of trees. Vossler et al. (2012) note that truthful preference revelation is possible when respondents believe they have at least a weak chance of influencing the decision. To ensure consequentiality of the valuation scenario, the introductory text to the survey and framing used in the DCE laid out the project partners, funding agencies and use of the survey results. For instance, it was explained that the answers to the survey and DCE could potentially serve as input for the design of future community management plans. The pictures included on the choice cards were improved after the pilot test to ensure their effectiveness by enhancing understanding by the respondents. Vietnamese translations of the choice cards were used (see figure 2 for English examples).

Analysis of the DCE. Prior to the analysis, so-called protesters were excluded from the sample. A respondent was identified as a protester if he or she selected the 'No Management' option in all of the presented choices and indicated (in a follow-up question) that the motivation to do so was either a lack of trust, lack of responsibility, or unwillingness to weigh the different attributes against each other (e.g., Meyerhoff and Liebe, 2010; Meyerhoff et al., 2014). In the coastal sample, nine protesters were identified of which five were part of the time payment vehicle sample and four of the money payment

\footnotetext{
${ }^{4} \mathrm{US} \$ 1 \approx \mathrm{VND} 23,000$ and thus $\mathrm{VND} 5,000 \approx \mathrm{US} \$ 0.22$ and $\mathrm{VND} 3,000 \mathrm{VND} \approx \mathrm{US} \$ 0.13$.
} 
Table 1. Attributes and attribute levels for the coastal discrete choice experiment

\begin{tabular}{|c|c|c|c|c|c|c|}
\hline \multirow[b]{2}{*}{ Attribute } & \multicolumn{3}{|c|}{ Time payment vehicle } & \multicolumn{3}{|c|}{ Money payment vehicle } \\
\hline & \# of levels & Levels & Opt-out & \# of levels & Levels & Opt-out \\
\hline Protection from storms and floods (in \% reduction in damages) & 4 & $50 ; 67 ; 83$ & 0 & 4 & $50 ; 67 ; 83$ & 0 \\
\hline $\begin{array}{l}\text { Seafood abundance in the lagoon (in \% increases in } \\
\text { abundance) }\end{array}$ & 4 & $10 ; 20 ; 30$ & 0 & 4 & $10 ; 20 ; 30$ & 0 \\
\hline Tourism to the mangrove area (in number of tourists per year) & 4 & $500 ; 650 ; 800$ & 350 & 4 & $500 ; 650 ; 800$ & 350 \\
\hline $\begin{array}{l}\text { Time spent tending and cleaning the mangrove area (in days, } \\
8 \text { h per day) }\end{array}$ & 5 & $1 ; 2 ; 3 ; 4$ & 0 & & - & - \\
\hline $\begin{array}{l}\text { Monthly contribution to a community mangrove fund (in VND } \\
\text { per month) }\end{array}$ & & - & - & 5 & $\begin{array}{l}25,000 ; 50,000 \\
\quad 75,000 ; 1,000,000\end{array}$ & 0 \\
\hline
\end{tabular}


Table 2. Attributes and attribute levels for the urban discrete choice experiment

\begin{tabular}{|c|c|c|c|c|c|c|}
\hline $\begin{array}{l}\text { Protection from storms and floods (in \% reduction in } \\
\text { damages) }\end{array}$ & 4 & $50 ; 67 ; 83$ & 0 & 4 & $50 ; 67 ; 83$ & 0 \\
\hline $\begin{array}{l}\text { Suitability for recreation and other activities (in changes of } \\
\text { suitability level) }\end{array}$ & 4 & Low; medium; high & Very low & 4 & Low; medium; high & Very low \\
\hline Tourism in Hue city (in \% increase in tourists) & 4 & $5 ; 10 ; 15$ & 0 & 4 & $5 ; 10 ; 15$ & 0 \\
\hline $\begin{array}{l}\text { Monthly contribution to a community pond fund (in VND } \\
\text { per month) }\end{array}$ & & - & - & 5 & 20,$000 ; 40,000 ; 80,000 ; 1,200,000$ & 0 \\
\hline
\end{tabular}




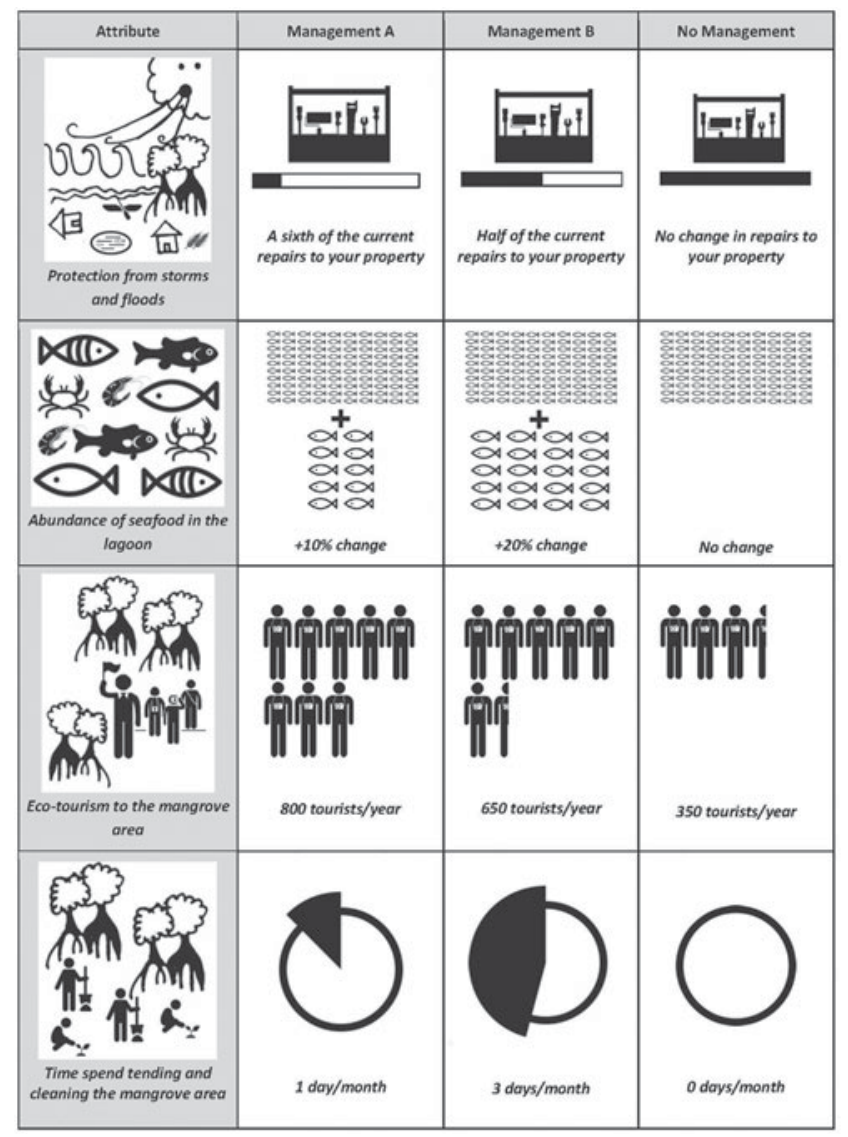

\begin{tabular}{|c|c|c|c|}
\hline Attribute & Management A & Management $\mathrm{B}$ & No Management \\
\hline \multirow{2}{*}{$\begin{array}{l}\text { Protection from storms and } \\
\text { floods }\end{array}$} & & & \\
\hline & $\begin{array}{l}\text { A third of the current } \\
\text { repairs to your property }\end{array}$ & $\begin{array}{l}\text { A sixth of the current } \\
\text { repairs to your property }\end{array}$ & $\begin{array}{c}\text { No change in repairs to } \\
\text { your property }\end{array}$ \\
\hline \multirow[t]{2}{*}{$\begin{array}{l}\text { Suitability for recreation } \\
\text { and other activities }\end{array}$} & & & \\
\hline & High & Medium & Very low \\
\hline \multirow[t]{2}{*}{ Tourism } & & & \\
\hline & $+5 \%$ & $+15 \%$ & No change \\
\hline \multirow[t]{2}{*}{$\begin{array}{c}\text { Contribution to } a \\
\text { community fund for pond } \\
\text { maintenance }\end{array}$} & ఏ & & \\
\hline & $120.000 \mathrm{dong} / \mathrm{month}$ & 40.000 dong/month & Odong/month \\
\hline
\end{tabular}

Figure 2. Example of choice cards for the coastal experiment with time payment vehicle (on the left) and the urban experiment with money payment vehicle (on the right). Note that in the urban and coastal surveys, both time and money payment vehicles were used. 
vehicle sample. In the urban sample, there were ten protesters in total, five in both of the samples.

The data of the DCE was analyzed using a random parameters logit (RPL) model in order to obtain individual-specific coefficients for each attribute (e.g., Brouwer et al., 2010; Koetse and Brouwer, 2016), implying that we can assess WTP distributions for the time experiment $\left(\mathrm{WTP}_{\text {time }}\right)$ and the money experiment $\left(\mathrm{WTP}_{\text {money }}\right)$. All ES attributes are included in the model as continuous variables, and for each attribute 3,200 Halton draws are taken from the triangular distribution (based on Czajkowski and Budziński, 2019). Those are restricted to positive values for the protection, seafood and recreation attributes due to theoretically expected positive preferences. For tourism the draws are taken from the triangular distribution without restriction since positive as well as negative preferences can be expected here. Triangular distributions are applied in order to be able to clearly visualize the WTP distributions for both payment vehicles and the different conversion rates, while there is a minimal reduction in model fit compared to the normal distribution. The payment vehicle values are redefined to be the negative of the variable and thereafter included in the model with a lognormal distribution and the standard deviation restricted to 0 , following the new baseline model to estimate WTP as suggested by Carson and Czajkowski (2019).

For the purpose of analyzing heterogeneity across the site-specific samples, additional models were estimated. These models include interaction terms between the payment vehicle and socio-demographic variables. The draws for the payment vehicles in these models are taken from negatively-restricted triangular distributions. Conventionally, when applying a lognormal distribution it is necessary to take the exponential of the coefficient for the payment vehicles in order to calculate WTP. This step is avoided through the application of triangular distributions and therefore makes it easier to interpret the coefficients of the interactions and the effects on WTP in these models. Moreover, for the purpose of investigating the interaction effects, this adjustment does not affect the results.

Values for the time attribute were converted to monetary values in the data set (i.e., before model estimation) by applying six alternative time-to-money conversion rates as described in the upcoming section. Using the output from the RPL models, the Krinsky and Robb (1986) procedure was applied to obtain 95 per cent confidence intervals of mean WTP estimates. Subsequently, respondent-specific parameter estimates were used to estimate a WTP for each respondent for each attribute, allowing for a clear visualization of differences in WTP distributions for the different payment vehicle experiments and for the six conversion rates. Mann-Whitney $U$ tests were applied to assess whether WTP distributions are significantly different between the two payment vehicle experiments and across the six conversion rates.

\subsubsection{Household survey}

The questionnaires used in the household surveys were to a large extent identical for both study sites (i.e., coastal and urban), consisting of eight main sections including 71 questions on: (1) Dependence on ES; (2) Environmental perceptions; (3) Happiness; (4) Risk perceptions; (5) DCE and DCE debriefing; (6) Community life; (7) Flood experiences; (8) Household life and demographics. The only differences can be found in the first section, since the ES that are delivered by the mangroves differ from those delivered by the urban ponds and those questions concern the use of specific services. The questionnaire was developed in close consultation with CSRD in Huế City in Vietnam, Potsdam University 
and Vrije University (VU) Amsterdam, and was translated into Vietnamese. During the pre-test survey and pilot, the questions were tested to check the clarity and consistency, and adjustments were made accordingly. The results of the household survey are used for the calculation of the conversion rates.

Time-to-money conversion rates. Six different types of conversion rates were used to take the required step of converting the willingness to spend time into monetary values. The first conversion rate involves the commonly applied generic market wage rate which the majority of valuation studies use. The following three are a wage and two different leisure rates, using individual-specific instead of generic wage values. The last two conversion rates are individual-specific weighted values of time that are based on additional information besides wages only.

Generic wage rate (VoT (wages, generic)): At the time of this research, the daily market wage rate for activities such as guarding, cleaning, building, planting trees and enforcement of regulations was VND130,000 in Quảng Lợi and VND150,000 in Huế City. This rate is applied to each respondent in the respective study site.

Individual-specific wage rate (VoT (wages, individual) $)$ : The survey included questions on daily wages for each respondent as well as the number of hours of paid work per day. This information was used to value an eight-hour work day per respondent. This approach is comparable to the one taken by Tilahun et al. (2015).

Individual-specific leisure rate (VoT (leisure low) and $\left.V o T_{\text {(leisure high) }}\right)$ : Adopting the individual-specific information on daily wages as specified above, the wage rate was transformed into two leisure rates by multiplying the wage rate with leisure rate $l$, either $1 / 3$ or 1.2 , together presenting the lower and upper bounds of leisure values that can be found in the literature (Cesario, 1976; Feather and Shaw, 1999; Alvarez-Farizo et al., 2001; Larson et al., 2004; Lee and Kim, 2005; Jara-Díaz et al., 2008).

Individual-specific weighted value of time (VoT (weighted low) and $V o T_{\text {(weighted high) }}$ ): In the calculation of this conversion rate, we assume that more than one activity could be sacrificed to contribute time and that this decision would depend on the composition of the current time spendings. Therefore, we assume that a person's value of time is not fully determined by either the value of work or by the value of leisure time, but that this value of time is instead determined by the range of work and leisure activities that a person participates in. We also assume that a person's value of time is a weighted value of the time spent on all these activities. For the calculation of this conversion rate, data on paid and unpaid hours of work (i.e., household work, subsistence activities) per day was used, as well as hours of leisure time for each respondent. For this we assume that respondents cannot exceed $18 \mathrm{~h}$ of work per day (including both paid and unpaid work) and that sleeping is included in leisure time. When the respondents' stated number of working hours exceeded this number, the number of hours was rescaled downwards so that the total equalled 18. A weighted value of time was calculated assuming that the value of unpaid work equals around 69 per cent of the value of leisure (based on Lee and Kim, 2005, and Eom and Larson, 2006). As such, the wage rate was applied for paid work time, one of the two leisure rates for the value of leisure time, and the appropriate rate depending on the selected leisure rate for unpaid work time. The value of time holds for a full day, so the $24 \mathrm{~h}$ were divided by three in order to obtain the value of an eight-hour day (see equation (2) for a summary of this calculation, where $l$ refers to the applied leisure rate). For those respondents that did not have a paid job, and thus there was no information on daily wage or paid work hours, the average daily wage rate of the total sample (i.e., of all coastal or all urban respondents) was used to calculate the value of leisure time and unpaid work time for these respondents. It has been shown that unemployed and 
retired people also have positive values for time (Lloyd-Smith et al., 2019), and therefore those respondents were included.

$$
\operatorname{VoT}_{(\text {weighted })}=\frac{\begin{array}{c}
\text { (Paid work hours }+0.69 \times l \times \text { unpaid work hours } \\
+l \times \text { leisure hours }) \times \text { wage }
\end{array}}{3} .
$$

In order to be able to make the calculations for the six time-to-money conversion rates, 113 respondents were eliminated from the samples because of missing data, irregularities in the data, and outliers regarding the variables that were needed for the calculations. After eliminating those respondents, there were 178 and 202 respondents left in the coastal and urban time experiment samples, respectively. Regarding the analyses for the money payment vehicle, all respondents were included in these samples since there was no indication that the missing or irregular answers to the relevant survey questions reveal irregular choice behavior in the DCE.

\section{Results}

\subsection{Data characteristics}

Tables 3 and 4 show the results for the key sample characteristics. In each site, KruskalWallis and Chi-squared tests were applied to test for differences across the money and time samples as well as the money and reduced time samples, which are the samples that are compared in the next sections of this paper. In the coastal samples, income levels are found to be significantly higher in the time and reduced time samples, and income from wages is found to be significantly higher in the reduced time sample. No significant differences were identified across the urban samples. A follow-up question on the perceived realism of the presented changes was included in the questionnaire. The results for this question show that the respondents (on average) agree with the statement, which suggests that respondents perceived the presented scenario as consequential. The statistical tests reveal that the level of realism is significantly higher in the coastal time sample compared to the coastal money sample.

The study sites differ in terms of socio-economic background. Table 4 shows that in the urban study site, income from wage labor on average accounts for more than 57 per cent of the household income. Many urban respondents participate in wage labor or small businesses, making wages the most important income source. Furthermore wage labor income serves as a proxy for market integration (e.g., Ensminger and Henrich, 2014; Vasco et al., 2017). The results in table 3 indicate that the level of market integration differs substantially between the urban and coastal study sites. In the coastal study site, most of the respondents (70 per cent) are fishermen and around 90 per cent of the fish catch is sold at market. The household income in this study site is therefore mostly made up of income from fisheries from the Tam Giang lagoon (54 per cent on average).

The values of time per day that were estimated through the five individualspecific conversion rates are lowest for the urban $V o T_{\text {(leisure low), averaging VND59,000 }}$ $(\sim \mathrm{US} \$ 2.5)$, and highest for the coastal $\left.V o T_{\text {(leisure high) }}\right)$, averaging VND280,000 $(\sim$ US\$12). The values are higher for men and higher in the coastal sample, and are positively correlated with household income. In the urban sample, the values of time are furthermore positively correlated with education and negatively correlated with age (except for $\mathrm{VoT}_{\text {(weighted high) }}$ ). In the coastal sample, age is negatively correlated with $\mathrm{VoT}_{\text {(leisure high) }}$ and positively correlated with $\mathrm{VoT}_{\text {(wages) }}$ and $\mathrm{VoT}_{\text {(weighted high), while for }}$ education, negative correlations are identified with $\mathrm{VoT}_{\text {(leisure high) }}$ and $\mathrm{VoT}_{\text {(weighted low) }}$. 
Table 3. Sample characteristics for both choice experiments in the coastal area

\begin{tabular}{|c|c|c|c|c|}
\hline \multirow[b]{2}{*}{ Variables } & \multirow[b]{2}{*}{ Description } & \multicolumn{3}{|c|}{ Sample values: mean (sd) } \\
\hline & & $\begin{array}{l}\text { Time } \\
\text { payment } \\
\text { vehicle, } \\
N=253\end{array}$ & $\begin{array}{l}\text { Time payment } \\
\text { vehicle, } N=178 \\
\text { (reduced sample) }\end{array}$ & $\begin{array}{l}\text { Money } \\
\text { payment } \\
\text { vehicle, } \\
N=252\end{array}$ \\
\hline Age & Age of respondent & $\begin{array}{c}47.47 \\
(13.09)\end{array}$ & $\begin{array}{c}46.97 \\
(13.47)\end{array}$ & $\begin{array}{c}48.43 \\
(13.53)\end{array}$ \\
\hline Education level & 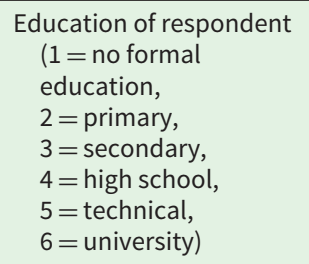 & $\begin{array}{c}2.29 \\
(1.06)\end{array}$ & $\begin{array}{c}2.25 \\
(1.11)\end{array}$ & $\begin{array}{c}2.27 \\
(1.09)\end{array}$ \\
\hline Gender & $\begin{array}{l}\text { Gender of respondent } \\
\quad(\text { male }=0, \text { female }=1)\end{array}$ & $\begin{array}{c}0.42 \\
(0.50)\end{array}$ & $\begin{array}{c}0.42 \\
(0.50)\end{array}$ & $\begin{array}{c}0.47 \\
(0.50)\end{array}$ \\
\hline Income & $\begin{array}{l}\text { Monthly household } \\
\text { income in VND } \\
\text { (continuous based on } \\
\text { averages of categories) }\end{array}$ & $\begin{array}{l}6.77 \text { million } \\
\text { (4.26 million) }\end{array}$ & $\begin{array}{l}7.22 \text { million } \\
\text { (4.08 million) }\end{array}$ & $\begin{array}{l}6.25 \text { million } \\
\text { (4.19 million) }\end{array}$ \\
\hline $\begin{array}{l}\text { Wage labor } \\
\text { income }\end{array}$ & $\begin{array}{l}\text { Percentage of household } \\
\text { income from wage } \\
\text { labor }\end{array}$ & $\begin{array}{c}9.68 \\
(23.33)\end{array}$ & $\begin{array}{c}11.57 \\
(24.72)\end{array}$ & $\begin{array}{c}6.87 \\
(18.98)\end{array}$ \\
\hline Consequentiality & $\begin{array}{l}\text { Level of agreement } \\
\text { (Likert scale, } 0 \text { to 10) } \\
\text { with the statement: 'I } \\
\text { believe the changes } \\
\text { shown in the } \\
\text { experiment can take } \\
\text { place in reality' }\end{array}$ & $\begin{array}{c}6.52 \\
(1.68)\end{array}$ & $\begin{array}{c}6.48 \\
(1.77)\end{array}$ & $\begin{array}{c}6.31 \\
(1.53)\end{array}$ \\
\hline
\end{tabular}

\subsection{Model estimation results and mean WTP estimates}

The results of the RPL models are presented in table 5 and appendix A in the online appendix. All the coefficients have the expected sign (i.e., positive for the ES and negative for the payment vehicles) and are significant at the 10 per cent level at least. As indicated by the larger coefficients, a percentage increase in seafood abundance (coastal) and a change in the level of recreation suitability (urban) are the attributes that the communities derive most utility from, followed by the specified changes in protection in the coastal area and changes in tourism in the urban area.

The results of the Krinsky and Robb simulations are presented in tables 6 and 7 . The numbers presented in these tables are marginal WTP for the changes in ES (i.e., the WTP per percentage increase in tourism or seafood abundance, or for an increase in the level of recreation suitability). The WTP estimates are highest when the time payments are converted with $\mathrm{VoT}_{\text {(leisure high) }}$ and lowest for the money payments. The differences in WTP estimates resulting from both experiments are large, but the extent of the difference depends on the ES and conversion rate. For instance, the WTP for 
Table 4. Sample characteristics for both choice experiments in the urban area

\begin{tabular}{|c|c|c|c|c|}
\hline \multirow[b]{2}{*}{ Variables } & \multirow[b]{2}{*}{ Description } & \multicolumn{3}{|c|}{ Sample values: mean (sd) } \\
\hline & & $\begin{array}{l}\text { Time } \\
\text { payment } \\
\text { vehicle, } \\
N=253\end{array}$ & $\begin{array}{l}\text { Time payment } \\
\text { vehicle, } N=202 \\
\text { (reduced sample) }\end{array}$ & $\begin{array}{l}\text { Money } \\
\text { payment } \\
\text { vehicle, } \\
N=252\end{array}$ \\
\hline Age & Age of respondent & $\begin{array}{c}48.45 \\
(13.50)\end{array}$ & $\begin{array}{c}47.55 \\
(13.32)\end{array}$ & $\begin{array}{c}47.87 \\
(12.73)\end{array}$ \\
\hline Education level & 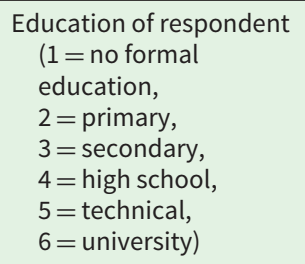 & $\begin{array}{c}3.89 \\
(1.53)\end{array}$ & $\begin{array}{c}3.89 \\
(1.56)\end{array}$ & $\begin{array}{c}3.88 \\
(1.55)\end{array}$ \\
\hline Gender & $\begin{array}{l}\text { Gender of respondent } \\
\quad(\text { male }=0, \text { female }=1)\end{array}$ & $\begin{array}{l}0.45 \\
(0.50)\end{array}$ & $\begin{array}{l}0.45 \\
(0.50)\end{array}$ & $\begin{array}{c}0.46 \\
(0.50)\end{array}$ \\
\hline Income & $\begin{array}{l}\text { Monthly household } \\
\text { income in VND } \\
\text { (continuous based on } \\
\text { averages of categories) }\end{array}$ & $\begin{array}{l}9.74 \text { million } \\
\text { (6.6 million) }\end{array}$ & $\begin{array}{l}9.48 \text { million } \\
\text { (5.32 million) }\end{array}$ & $\begin{array}{l}9.08 \text { million } \\
\text { (4.96 million) }\end{array}$ \\
\hline $\begin{array}{l}\text { Wage labor } \\
\text { income }\end{array}$ & $\begin{array}{l}\text { Percentage of household } \\
\text { income from wage } \\
\text { labor }\end{array}$ & $\begin{array}{c}57.67 \\
(41.98)\end{array}$ & $\begin{array}{c}63.71 \\
(41.28)\end{array}$ & $\begin{array}{c}59.76 \\
(42.43)\end{array}$ \\
\hline Consequentiality & $\begin{array}{l}\text { Level of agreement } \\
\text { (Likert scale, } 0 \text { to } 10 \text { ) } \\
\text { with the statement: 'I } \\
\text { believe the changes } \\
\text { shown in the } \\
\text { experiment can take } \\
\text { place in reality' }\end{array}$ & $\begin{array}{c}6.33 \\
(1.59)\end{array}$ & $\begin{array}{c}6.30 \\
(1.62)\end{array}$ & $\begin{array}{c}6.30 \\
(1.45)\end{array}$ \\
\hline
\end{tabular}

a given increase in seafood abundance is about 20 times larger when estimated via $\mathrm{VoT}_{(\text {leisure high) }}$ compared to the WTP resulting from the money payment vehicle. The WTP for a given increase in tourism in the urban study site is about 3.5 times larger when using $\mathrm{VoT}_{\text {(leisure low) }}$ compared to the money payment vehicle. There are also large differences in WTP estimates across the conversion rates. Most importantly, the differences in $\mathrm{WTP}$ from $\mathrm{VoT}_{\text {(wages,generic) }}$ and $\mathrm{VoT}_{\text {(wages,individual) }}$ differ substantially and show that not accounting for heterogeneity in wages results in an underestimation of WTP. Overall the differences in WTP estimates are substantial, depending on the payment vehicle that is used, but also the conversion rate has a strong effect on the WTP estimates that are obtained.

In section 3.1, it was shown that income and income from wage labor differ significantly across the coastal money and reduced time samples. Namely, households with a higher income and more income from wage labor were overrepresented in the reduced time samples. No significant differences were identified across the urban samples. The results of the RPL models with the interactions are used to analyze the effect of the sample differences in the coastal study site. The results of these models are included in 
Table 5. Results of the RPL models for both coastal and urban experiments

\begin{tabular}{|c|c|c|c|c|c|c|c|c|}
\hline \multirow[b]{3}{*}{ Attribute } & \multicolumn{4}{|c|}{ Coastal experiments } & \multicolumn{4}{|c|}{ Urban experiments } \\
\hline & \multicolumn{2}{|c|}{ Money payment vehicle } & \multicolumn{2}{|c|}{ Time payment vehicle } & \multicolumn{2}{|c|}{ Money payment vehicle } & \multicolumn{2}{|c|}{ Time payment vehicle } \\
\hline & Coefficient & SE & Coefficient & SE & Coefficient & SE & Coefficient & SE \\
\hline \multicolumn{9}{|l|}{ Means of random parameters } \\
\hline Protection from storms and floods & $0.005^{\star}$ & 0.003 & $0.006^{\star \star \star}$ & 0.002 & $0.007^{\star \star \star}$ & 0.002 & $0.013^{\star \star \star}$ & 0.002 \\
\hline Seafood abundance & $0.092^{\star \star \star}$ & 0.004 & $0.096^{\star \star \star}$ & 0.004 & - & - & - & - \\
\hline Recreation suitability & - & - & - & - & $0.308^{\star \star \star}$ & 0.025 & $0.362^{\star \star \star}$ & 0.027 \\
\hline Tourism & $0.001^{\star *}$ & 0.000 & $0.001^{\star \star \star}$ & 0.000 & $0.029^{\star \star *}$ & 0.009 & $0.039^{\star \star *}$ & 0.008 \\
\hline Time payments & - & - & $-1.211^{\star \star \star}$ & 0.073 & - & - & $-1.065^{\star \star \star}$ & 0.072 \\
\hline Money payments & $-4.235^{\star \star \star}$ & 0.063 & - & - & $-4.548^{\star \star \star}$ & 0.052 & - & - \\
\hline ASC opt-out & $-41.544^{\star \star \star}$ & 11.696 & $-57.666^{\star \star \star}$ & 18.108 & $-12.775^{\star \star \star}$ & 3.082 & $-22.017^{\star \star \star}$ & 5.938 \\
\hline \multicolumn{9}{|c|}{ Standard deviations of random parameters } \\
\hline Protection from storms and floods & $0.005^{\star}$ & 0.003 & $0.006^{\star \star \star}$ & 0.002 & $0.007^{\star \star \star}$ & 0.002 & $0.013^{\star \star \star}$ & 0.002 \\
\hline Seafood abundance & $0.092^{\star \star \star}$ & 0.004 & $0.096^{\star \star \star}$ & 0.004 & - & - & - & - \\
\hline Recreation suitability & & & - & - & $0.308^{\star \star \star}$ & 0.025 & $0.362^{\star \star \star}$ & 0.027 \\
\hline Tourism & $0.001^{\star \star}$ & 0.000 & 0.002 & 0.001 & $0.167^{\star \star \star}$ & 0.025 & $0.182^{\star \star \star}$ & 0.024 \\
\hline Time payments & - & - & 0.0 & - & - & - & 0.0 & - \\
\hline Money payments & 0.0 & - & - & - & 0.0 & - & - & - \\
\hline ASC opt-out & $49.678^{\star \star \star}$ & 12.873 & $64.830^{\star \star \star}$ & 18.959 & $15.468^{\star \star \star}$ & 3.310 & $28.587^{\star \star \star}$ & 6.376 \\
\hline Observations & 2,480 & & 2,480 & & 2,470 & & 2,480 & \\
\hline$N$ & 248 & & 248 & & 247 & & 248 & \\
\hline AIC & 3,228 & & 3,177 & & 3,677 & & 3,565 & \\
\hline Pseudo $R^{2}$ (adjusted) & 0.41 & & 0.42 & & 0.33 & & 0.35 & \\
\hline Log likelihood & $-1,606$ & & $-1,581$ & & $-1,831$ & & $-1,775$ & \\
\hline
\end{tabular}


Table 6. Results of the Krinsky and Robb simulations for the coastal experiments in Vietnamese dong per household per month $($ US\$1 $\approx$ VND23,000)

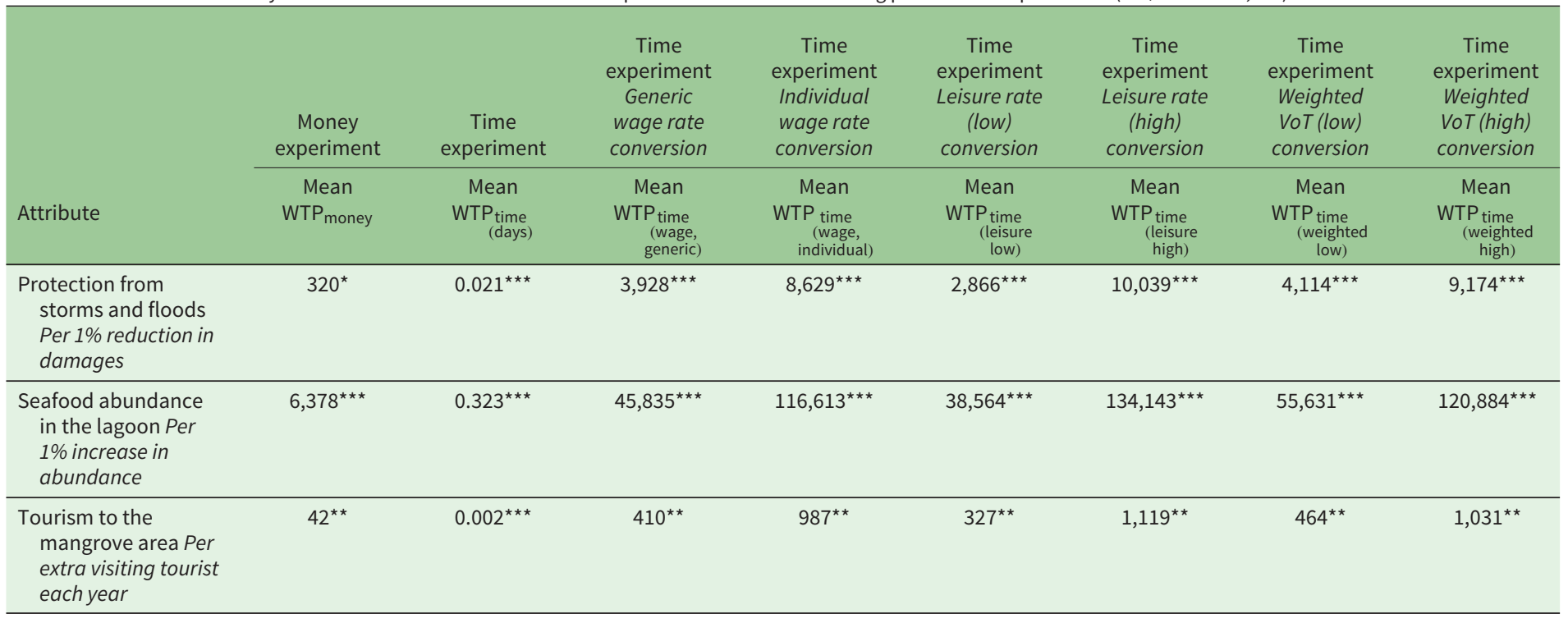

Statistical significance: ${ }^{\star} 10 \% ;{ }^{* *} 5 \% ;{ }^{* \star} 1 \%$. 
Table 7. Results of the Krinsky and Robb simulations for the urban experiments in Vietnamese dong per household per month (US\$1 $\approx$ VND23,000)

\begin{tabular}{|c|c|c|c|c|c|c|c|c|}
\hline & $\begin{array}{c}\text { Money } \\
\text { experiment }\end{array}$ & $\begin{array}{c}\text { Time } \\
\text { experiment }\end{array}$ & $\begin{array}{c}\text { Time } \\
\text { experiment } \\
\text { Generic } \\
\text { wage rate } \\
\text { conversion }\end{array}$ & $\begin{array}{c}\text { Time } \\
\text { experiment } \\
\text { Individual } \\
\text { wage rate } \\
\text { conversion }\end{array}$ & $\begin{array}{l}\text { Time } \\
\text { experiment } \\
\text { Leisure rate } \\
\text { (low) } \\
\text { conversion }\end{array}$ & $\begin{array}{l}\text { Time } \\
\text { experiment } \\
\text { Leisure rate } \\
\text { (high) } \\
\text { conversion }\end{array}$ & $\begin{array}{l}\text { Time } \\
\text { experiment } \\
\text { Weighted } \\
\text { VoT (low) } \\
\text { conversion }\end{array}$ & $\begin{array}{l}\text { Time } \\
\text { experiment } \\
\text { Weighted } \\
\text { VoT (high) } \\
\text { conversion }\end{array}$ \\
\hline Attribute & $\begin{array}{c}\text { Mean } \\
\text { WTP } \\
\text { money }\end{array}$ & $\begin{array}{c}\text { Mean } \\
\text { WTP } \\
\text { (dime } \\
\text { (days) }\end{array}$ & $\begin{array}{c}\text { Mean } \\
\text { WTP time } \\
\text { (wage, } \\
\text { generic) }\end{array}$ & $\begin{array}{c}\text { Mean } \\
\text { WTP time } \\
\text { (wage, } \\
\text { individual) }\end{array}$ & $\begin{array}{c}\text { Mean } \\
\text { WTP time } \\
\text { (leisure } \\
\text { low) }\end{array}$ & $\begin{array}{c}\text { Mean } \\
\text { WTP time } \\
\text { (leisure } \\
\text { high) }\end{array}$ & $\begin{array}{c}\text { Mean } \\
\text { WTP time } \\
\text { (weighted } \\
\text { low) }\end{array}$ & $\begin{array}{c}\text { Mean } \\
\text { WTP time } \\
\text { (weighted } \\
\text { high) }\end{array}$ \\
\hline $\begin{array}{l}\text { Protection from } \\
\text { storms and floods } \\
\text { Per } 1 \% \text { reduction in } \\
\text { damages }\end{array}$ & $641^{\star \star \star}$ & $0.038^{\star \star \star *}$ & $9,555^{\star \star \star}$ & $16,279^{\star \star *}$ & $5,426^{\star \star *}$ & $26,270^{\star \star \star *}$ & $8,643^{\star * *}$ & $17,287^{\star \star \star}$ \\
\hline $\begin{array}{l}\text { Recreation suitability } \\
\text { Per increase in } \\
\text { recreation level }\end{array}$ & $29.061^{\star \star \star}$ & $1,049^{\star \star \star}$ & $221,293^{\star \star \star}$ & $381,924^{\star \star \star}$ & $127,308^{\star \star \star}$ & $624,224^{\star \star \star}$ & $202,315^{\star \star \star}$ & $404,812^{\star \star \star}$ \\
\hline $\begin{array}{l}\text { Tourism to the } \\
\text { mangrove area Per } \\
\text { extra visiting tourist } \\
\text { each year }\end{array}$ & $2,757^{\star \star \star}$ & $0.113^{\star \star *}$ & $17,788^{* * *}$ & $29,681^{\star \star *}$ & $9,894^{\star \star *}$ & $45,736^{\star \star \star}$ & $15,335^{\star \star \star}$ & $31,440^{\star * *}$ \\
\hline
\end{tabular}

Statistical significance: ${ }^{\star \star \star} 1 \%$. 
appendix B. For the income variable, a significant positive effect was found for the money payments while no significant effect was found for the time payments. Households with a higher income were under-represented in the coastal money sample, and therefore accounting for this sample difference would lead to an increase in the estimated mean $\mathrm{WTP}_{\text {money. }}$ For the income from wage labor variable, no significant effect was found for the money payments while a significant negative effect was found for the time payments. Since households with more income from wage labor were over-represented in the time sample, accounting for this sample difference would lead to an increase in the estimated mean WTP values for all the time estimations. Both of the described results are consistent with theory. Households with a higher income are willing to pay more in terms of money and households with more income from wage labor (i.e., a higher degree of market integration) are willing to pay less in terms of time. Additionally, the models including interactions show that several other variables may explain both people's preferences and differences in WTP between time and money payment vehicles in rural and urban areas. Income, gender, age and education all have different effects (in terms of magnitude of the coefficient and/or in terms of sign) on time and money preferences in both the coastal and the urban areas.

Due to significant differences across the coastal samples, we calculate the effects on WTP when accounting for this heterogeneity as a robustness check. The difference in $\mathrm{WTP}_{\text {money }}$ is calculated by applying the results of the interaction models in appendix $\mathrm{B}$ to the different sample compositions (i.e., gender, age, education level, household income and income from wage labor). Based on this calculation, we find that mean $\mathrm{WTP}_{\text {money }}$ would increase by 1.35 per cent when the time sample composition instead of the money sample composition is applied. Similarly, $\mathrm{WTP}_{\text {time }}$ would increase by 0.63 per cent when the money sample composition instead of the time sample composition is applied. These differences in WTP are negligible compared to the minimum of 604 per cent difference in WTP that we find between both payment vehicles in the coastal area (see table 6). The identified sample differences therefore do not affect the presented conclusions on differences in WTP resulting from the time and money payment experiments.

\subsection{Comparison of WTP distributions}

Figure 3 presents an overview of the coastal WTP distributions that result from the calculation of respondent-specific WTP values using the RPL model outcomes. As with the results of the Krinsky and Robb simulations, higher WTP estimates are found for the time experiment for all conversion rates. Yet, these distributions appear to be more dispersed compared to the distribution of the WTP values for the money payments. As shown in figure 4, WTP distributions from experiments in the urban study site reveal comparable patterns to the coastal results in terms of the shape of WTP distributions. Compared to the coastal results, however, the distributions for all conversion rates overlap more for the tourism attribute.

With respect to the more dispersed WTP distributions for the time experiments, no differences are found in the data related to how easy or difficult the respondents find it to make choices in the two experiments, levels of certainty about the choices or the number of protest votes. Since payment vehicles were presented as coercive, the dispersed distributions could also be explained by differences in trust, acceptability and expected cooperation between the two types of payment. Namely, issues such as free riding could play a role in the choice-making process given the public good characteristics of flood protection. A list of follow-up questions was included in the questionnaire to investigate 
WTP for reductions in damages in time and money WTP for an increase in recreation level in time and money
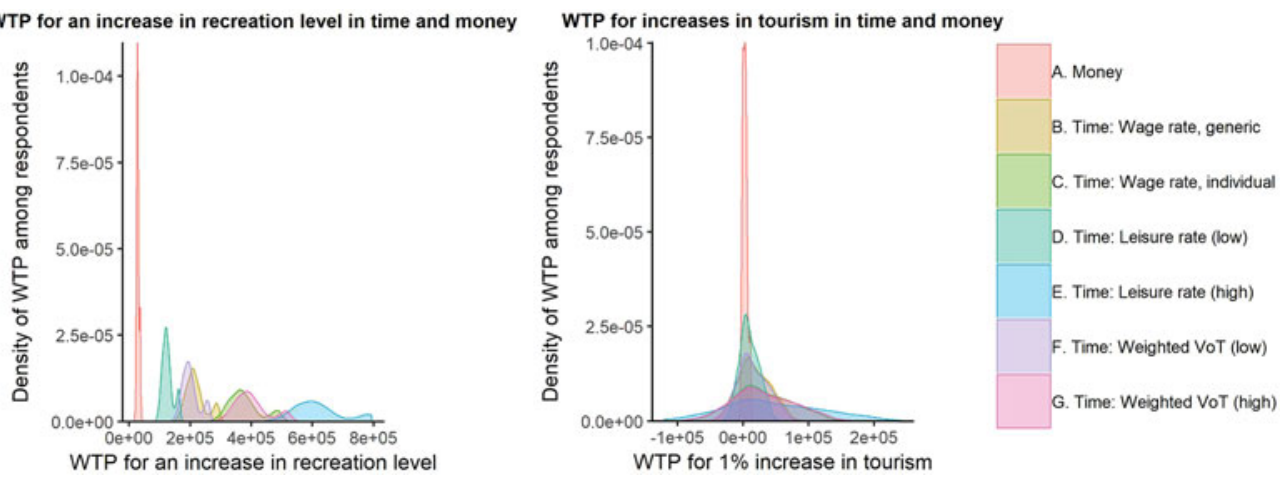

Figure 4. Willingness to pay (WTP) distributions for money and time (using six different conversion rates) for the urban attributes 'protection from storms and floods' (left panel), 'recreation suitability' (middle panel) and 'tourism' (right panel). 
perceived differences in these aspects across the types of payment. Three statements were included to measure expected cooperation, asking for the respondent's level of agreement (Likert scale, 0-10) regarding if all community members are able to contribute either time or money, if they expect their community members to also do so, and whether this would be easy to enforce. In both study sites, comparable means but higher variance (i.e., standard deviation) were identified in the reduced time samples for the second statement. Significantly higher means and lower variance were identified for the first and last statements (Kruskal-Wallis tests, urban: $p=0.015$ and $p=0.091$, coastal: $p=0.001$ and $p=0.042$, both respectively). In addition, a higher level and lower variance for trust in the time payments were identified in the urban study site (Kruskal-Wallis, $p=0.000$ ) and the same result was found for acceptability concerning time contributions in the coastal study site (Kruskal-Wallis, $p=0.000$ ). Overall the results presented in this paragraph suggest that these aspects do not explain the more dispersed WTP time distributions.

The higher dispersions are more likely to be a reflection of the fact that people have different perceptions of time, while this is less the case for money payments. There can be differences in how people perceive time used for leisure and time spent working. Moreover, working time can include farming, fishing or trading, which may all result in different values of time across respondents. This suggests that more understanding is needed on how people perceive and value time in choice experiments, potentially leading to more accurate WTP estimates and WTP distributions.

To investigate whether the WTP distributions are significantly different between the two experiments and between the different conversion rates, Mann-Whitney $U$ tests are applied to all the different distributions per attribute. The results of these analyses show that the differences between distributions are statistically significant at the 10 per cent level at least, except for the comparison of $\mathrm{VoT}_{\text {(wages,individual) }}$ and $\mathrm{VoT}_{\text {(weighted high) }}$ as well as the comparison of $\mathrm{VoT}_{\text {(wages,generic) }}$ and $\mathrm{VoT}_{\text {(weighted low) }}$, both for the urban tourism attribute. ${ }^{5}$ In conclusion, the graphical presentation of WTP distributions in figures 3 and 4, the Krinsky and Robb simulation results in tables 6 and 7, and results from the Mann-Whitney $U$ tests all together reveal that the payment vehicle used, as well as the conversion rates, substantially affects WTP estimates and WTP distributions.

\section{Conclusions and discussion}

The main objective of this paper was to assess differences in the results of choice experiments that aim to value changes in ES as a result of EbA measures, using time and money as payment vehicles in a developing country context, and with a specific focus on the time-to-money conversion rate. There is a need to obtain more accurate WTP estimates of EbA measures in order to guide investments in EbA. The payment vehicle is an important element of a choice experiment, and stated preference studies in general, since it is required for calculating WTP. Due to subsistence livelihoods, lower incomes and limited market integration, the use of a standard money payment vehicle can be problematic in the context of developing countries and can lead to inaccurate WTP estimates (Alam, 2006; Kenter et al., 2011; Gibson et al., 2016). Time-based payment vehicles have frequently been used as an alternative to money, but only a limited number of studies have compared results from different payment vehicles, and their findings are ambiguous. In this paper, we therefore aimed to compare WTP estimates resulting from choice experiments that use time and money payment vehicles. Moreover, we address the crucial issue

\footnotetext{
${ }^{5}$ Detailed results from the Mann-Whitney $U$ tests are available upon request from the authors.
} 
of how to convert time into money in more detail, especially because most previous studies only use a generic market wage rate and thus ignore heterogeneity in the value of time across respondents. In this study, we propose and apply an alternative approach which is more comprehensive and individual-specific. This approach includes applying a range of individual-specific rates alongside the commonly applied generic market wage rate. This range includes an individual-specific wage rate, two different leisures rates and two weighted values of time.

In the results of this study, the WTP estimates are higher with a time payment vehicle for all conversion rates. This finding could be interpreted to mean that a time payment vehicle performs better by allowing respondents to make choices that fully reflect their preferences. These findings correspond to those from a number of previous studies where higher WTP values were found in experiments using time payment vehicles (Alam, 2006; Casiwan-Launio et al., 2011) but also contrasts with the opposite and inconclusive findings of others which include differing conclusions depending on the conversion rate (O'Garra, 2009; Vondolia et al., 2014; Gibson et al., 2016). The more dispersed distributions that are found for the converted time values are in line with previous studies that identified increased confidence intervals and uncertainty in time experiments (Larson et al., 2004; Vondolia and Navrud, 2019).

In contrast to previous studies, we are the first to apply five alternative conversion rates that are all individual-specific next to the commonly applied generic market wage rate. We find that applying a generic instead of individual-specific market rate results in an underestimation of WTP, aligning with the findings presented in Tilahun et al. (2015). We argue that the weighted value of time is a more suitable conversion rate than the rates widely applied in the literature. However, there are some uncertainties related to our conversion approaches. A concern related to the use of a daily wage is that people in developing countries might not work a set number of days per week or might participate in seasonal work. At the same time, many might work in informal settings such as trading. They therefore do not receive a formal wage and thus appear in the data as a respondent without earnings. Additional individual-specific information could therefore be used to refine the conversion rates and better capture the differences in perceptions of time, possibly leading to more accurate WTP estimates. A second concern relates to the applied wage fractions for the estimation of leisure and unpaid work time values. These fractions are based on the range found in previous studies, of which none was conducted in a developing country context, while differences in these factors across the developed and developing world could be expected.

Based on our findings we have four recommendations for stated preferences studies that aim to estimate the welfare effects of EbA in developing countries. First, we encourage practitioners of stated preference studies to consider using a time payment vehicle in developing country contexts. The payment vehicle is highly accepted, as indicated by the positive values and limited protest votes recorded in the data set, and results in higher WTP estimates, possibly because respondents can express their preferences more freely. Second, we encourage future studies that use a time payment vehicle to apply individual-specific time-to-money conversion rates to account for heterogeneity in time values across respondents. Third, we show that converted time values can differ substantially, based on the conversion rate; we therefore want to highlight the need for sensitivity analyses when converted time values are used in cost benefit analyses, for instance by providing a lower and upper range estimate based on different conversion rates. Fourth, due to the challenges faced when converting time to money, we also suggest presenting time values supplementary to the converted and thus monetary values in the final results 
of stated preference studies. For the purpose of solely selecting a suitable EbA measure, time values are just as informative and do not include the added uncertainties that come with converting time to monetary values.

There are several issues that deserve attention in further research. First, the development and application of a suitable conversion rate is an important aspect for stated preference studies that use time payments, since this conversion rate is crucial for the quality and reliability of the WTP estimates. In many studies, including this one, time values are transformed into monetary values with measures based on the wage rate. However, previous findings by Lloyd-Smith et al. (2019) and Czajkowski et al. (2019) suggest that values of time depend to a large extent on other factors besides wages. Future stated preference studies that use time as the payment vehicle may focus on assessing these other factors, and by doing so derive more suitable values of time. For example, further improvement could come from detailed information on current time allocation, the monetary values that are attached to the different activities conducted by the respondent, and information on which current activity the respondent would be giving up in order to be able to contribute time. This could go hand in hand with the exploration of conversion rates that are not based on wages to start with. This type of conversion rate could be promising due to lower information needs and elimination of wage and leisure value related uncertainties.

Second, future studies may focus on investigating the drivers of the disparities in WTP estimates so that more information becomes available on when, and why, a time or money payment vehicle is more appropriate to use in certain socio-economic and cultural contexts. Gibson et al. (2016) and Casiwan-Launio et al. (2011) both hint at the influence of market integration on WTP disparities, of which we also find evidence in this study. More extensive analyses and further study would be necessary to reveal and confirm the relevant factors that may underlie the conclusions presented in this paper. Preferences for time and money clearly vary across important dimensions, which could also include personal values and perceptions. Lastly, we want to invite researchers to conduct studies on the value of leisure time in developing countries, since to the best of our knowledge no such study is available yet.

Supplementary material. The supplementary material for this article can be found at https://doi.org/10. 1017/S1355770X20000108.

Acknowledgements. We are grateful for funding for the ResilNam Urban and ResilNam Coastal projects from the Global Resilience Partnership through the Water Window and funding from NWO-WOTRO through the Urbanising Deltas of the World programme, project number W07.69.206. We also thank participants of the $25^{\text {th }}$ Ulvön Conference and Workshop on Non-Market Valuation in Ulvön, 19-21 June 2018, for useful comments and suggestions. Thanks also to our project partners, Potsdam University and CSRD, and the students from Huế University, for the fruitful collaboration and participation in the data collection activities. Finally, we thank two anonymous reviewers for suggestions and comments.

\section{References}

Abramson A, Becker N, Garb Y and Lazarovitch N (2011) Willingness to pay, borrow, and work for rural water service improvements in developing countries. Water Resources Research 47, W11512.

Alam K (2006) Valuing the environment in developing countries: problems and potentials. Asia Pacific Journal on Environment and Development 13, 27-44.

Alvarez-Farizo B, Hanley N and Barberán R (2001) The value of leisure time: a contingent rating approach. Journal of environmental Planning and Management 44, 681-699. 
Brouwer R, Dekker T, Rolfe J and Windle J (2010) Choice certainty and consistency in repeated choice experiments. Environmental and Resource Economics 46, 93-109.

Bubeck P, Botzen WJW, Suu LTT and Aerts JCJH (2012) Do flood risk perceptions provide useful insights for flood risk management? Findings from central Vietnam. Journal of Flood Risk Management 5, 295-302.

Carson RT and Czajkowski M (2019) A new baseline model for estimating willingness to pay from discrete choice models. Journal of Environmental Economics and Management 95, 57-61.

Carson RT and Groves T (2007) Incentive and informational properties of preference questions. Environmental and Resource Economics 37, 181-210.

Casiwan-Launio C, Shinbo T and Morooka Y (2011) Island villagers' willingness to work or pay for sustainability of a marine fishery reserve: case of San Miguel Island, Philippines. Coastal Management 39, 459-477.

Cesario FJ (1976) Value of time in recreation benefit studies. Land Economics 52, 32-41.

Christie M, Fazey I, Cooper R, Hyde T and Kenter JO (2012) An evaluation of monetary and nonmonetary techniques for assessing the importance of biodiversity and ecosystem services to people in countries with developing economies. Ecological Economics 83, 67-78.

Czajkowski M and Budziński W (2019) Simulation error in maximum likelihood estimation of discrete choice models. Journal of Choice Modelling 31, 73-85.

Czajkowski M, Giergiczny M, Kronenberg J and Englin J (2019) The individual travel cost method with consumer-specific values of travel time savings. Environmental and Resource Economics 74, 961-984.

Dasgupta S, Laplante B, Meisner C, Wheeler D and Yan J (2009) The impact of sea level rise on developing countries: a comparative analysis. Climatic Change 93, 379-388.

Diafas I, Barkmann J and Mburu J (2017) Measurement of bequest value using a non-monetary payment in a choice experiment - the case of improving forest ecosystem services for the benefit of local communities in rural Kenya. Ecological Economics 140, 157-165.

DKKV (Hrsg., 2019) Strong roots, strong women: Women and ecosystem-based adaptation to flood risk in Central Vietnam. DKKV-Schriftenreihe Nr. 61, March 2019, Bonn.

Ensminger J and Henrich J (eds) (2014) Experimenting with Social Norms: Fairness and Punishment in Cross-Cultural Perspective. New York City: Russel Sage Foundation.

Eom YS and Larson DM (2006) Valuing housework time from willingness to spend time and money for environmental quality improvements. Review of Economics of the Household 4, 205-227.

Feather P and Shaw WD (1999) Estimating the cost of leisure time for recreation demand models. Journal of Environmental Economics and Management 38, 49-65.

Gibson JM, Rigby D, Polya DA and Russell N (2016) Discrete choice experiments in developing countries: willingness to pay versus willingness to work. Environmental and Resource Economics 65, 697-721.

Gupta J, Hurley F, Grobicki A, Keating T, Stoett P, Baker E, Guhl A, Davies J and Ekins P (2019) Communicating the health of the planet and its links to human health. The Lancet Planetary Health 3, 204-206.

Hanley N, Wright RE and Adamowicz V (1998) Using choice experiments to value the environment. Environmental and Resource Economics 11, 413-428.

Hardner JJ (1996) Measuring the value of potable water in partially monetized rural economies. JAWRA Journal of the American Water Resources Association 32, 1361-1366.

Hudson P, Pham M and Bubeck P (2019) An evaluation and monetary assessment of the impact of flooding on subjective wellbeing across genders in Vietnam. Climate and Development 11, 623-637.

Hung LT, Loomis JB and Thinh VT (2007) Comparing money and labour payment in contingent valuation: the case of forest fire prevention in Vietnamese context. Journal of International Development 19, 173-185.

Jara-Díaz SR, Munizaga MA, Greeven P, Guerra R and Axhausen K (2008) Estimating the value of leisure from a time allocation model. Transportation Research Part B: Methodological 42, 946-957.

Johnston RJ, Boyle KJ, Adamowicz W, Bennett J, Brouwer R, Cameron TA, Hanemann WM, Hanley N, Ryan M, Scarpa R, Tourangeau R and Vossler CA (2017) Contemporary guidance for stated preference studies. Journal of the Association of Environmental and Resource Economists 4, 319-405.

Jongman B, Winsemius HC, Aerts JC, de Perez EC, van Aalst MK, Kron W and Ward PJ (2015) Declining vulnerability to river floods and the global benefits of adaptation. Proceedings of the National Academy of Sciences 112, E2271-E2280. 
Kamuanga M, Swallow BM, Sigué H and Bauer B (2001). Evaluating contingent and actual contributions to a local public good: Tsetse control in the Yale agro-pastoral zone, Burkina Faso. Ecological Economics 39, 115-130.

Kenter JO, Hyde T, Christie M and Fazey I (2011) The importance of deliberation in valuing ecosystem services in developing countries - evidence from the Solomon Islands. Global Environmental Change 21, 505-521.

Koetse MJ and Brouwer R (2016) Reference dependence effects on WTA and WTP value functions and their disparity. Environmental and Resource Economics 65, 723-745.

Krinsky I and Robb AL (1986) On approximating the statistical properties of elasticities. The Review of Economics and Statistics 68, 715-719.

KTTV (2017) Thua Thien Hue: Khan truong khac phuc hau qua sau mua lu. Available at http://www.kttvqg.gov.vn/kttv-voi-san-xuat-va-doi-song-106/thua-thien-hue--khan-truong-khacphuc-hau-qua-sau-mua-lu-1395.html (in Vietnamese).

Lancaster KJ (1966) A new approach to consumer theory. Journal of Political Economy 74, 132-157.

Larson DM and Shaikh SL (2004) Recreation demand choices and revealed values of leisure time. Economic Inquiry 42, 264-278.

Larson DM, Shaikh SL and Layton D (2004) Revealing preferences for leisure time from stated preference data. American Journal of Agricultural Economics 86, 307-320.

Lee K and Kim IM (2005) Estimating the value of leisure time in Korea. Applied Economics Letters 12, 639-641.

Lloyd-Smith P, Abbott JK, Adamowicz W and Willard D (2019) Decoupling the value of leisure time from labor market returns in travel cost models. Journal of the Association of Environmental and Resource Economists 6, 215-242.

McFadden D (1974) Conditional logit analysis of qualitative choice behavior. In Zarembka P (ed.), Frontiers of Econometrics. New York: Academic Press, pp. 105-142.

Meyerhoff J and Liebe U (2010) Determinants of protest responses in environmental valuation: a metastudy. Ecological Economics 70, 366-374.

Meyerhoff J, Mørkbak MR and Olsen SB (2014) A meta-study investigating the sources of protest behaviour in stated preference surveys. Environmental and Resource Economics 58, 35-57.

Morrison MD, Blamey RK and Bennett JW (2000) Minimising payment vehicle bias in contingent valuation studies. Environmental and Resource Economics 16, 407-422.

O'Garra T (2009) Bequest values for marine resources: how important for indigenous communities in lessdeveloped economies?. Environmental and Resource Economics 44, 179.

Parker RS (2006) Hazards of Nature, Risks to Development: An IEG Evaluation of World Bank Assistance for Natural Disasters. Washington, DC: World Bank.

Pondorfer A and Rehdanz K (2018) Eliciting preferences for public goods in nonmonetized communities: accounting for preference uncertainty. Land Economics 94, 73-86.

Rai RK and Scarborough H (2013) Economic value of mitigation of plant invaders in a subsistence economy: incorporating labour as a mode of payment. Environment and Development Economics 18, 225-244.

Secretariat of the Convention on Biological Diversity (2009). Connecting Biodiversity and Climate Change Mitigation and Adaptation. Report of the Second Ad Hoc Technical Expert Group on Biodiversity and Climate change. CBD Technical Series No. 41. Montreal, Quebec.

Shyamsundar P and Kramer RA (1996) Tropical forest protection: an empirical analysis of the costs borne by local people. Journal of Environmental Economics and Management 31, 129-144.

Tilahun M, Vranken L, Muys B, Deckers J, Gebregziabher K, Gebrehiwot K, Bauer H and Mathijs E (2015) Rural households' demand for frankincense forest conservation in Tigray, Ethiopia: a contingent valuation analysis. Land Degradation \& Development 26, 642-653.

UN Environment (ed.) (2019) Global Environment Outlook - GEO-6: Healthy Planet, Healthy People. Cambridge, UK: Cambridge University Press. Available at doi:10.1017/9781108627146.

Vasco C, Tamayo G and Griess V (2017) The drivers of market integration among indigenous peoples: evidence from the Ecuadorian Amazon. Society \& Natural Resources 30, 1212-1228.

Vietnam News (2017) Historic flood hits Hue killing 9. Viet Nam News, November 7. Available at https:// vietnamnews.vn/society/417032/historic-flood-hits-hue-killing-9.html. 
Vondolia GK and Navrud S (2019) Are non-monetary payment modes more uncertain for stated preference elicitation in developing countries? Journal of Choice Modelling 30, 73-87.

Vondolia GK, Eggert H, Navrud S and Stage J (2014) What do respondents bring into contingent valuation? A comparison of monetary and labour payment vehicles. Journal of Environmental Economics and Policy 3, 253-267.

Vossler CA, Doyon M and Rondeau D (2012) Truth in consequentiality: theory and field evidence on discrete choice experiments. American Economic Journal: Microeconomics 4, 145-171.

Whittington $\mathbf{D}$ (2002) Improving the performance of contingent valuation studies in developing countries. Environmental and Resource Economics 22, 323-367.

WWAP (United Nations World Water Assessment Programme)/UN-Water (2018) The United Nations World Water Development Report 2018. Nature-Based Solutions for Water. Paris: UNESCO.

Cite this article: Hagedoorn LC, Koetse MJ, van Beukering PJH, Brander LM (2020). Time equals money? Valuing ecosystem-based adaptation in a developing country context. Environment and Development Economics 25, 482-508. https://doi.org/10.1017/S1355770X20000108 